seven species are endemic to Australia and restricted to the genus Acacia for their host plants. Gladys Carey continues her study of the embryology of viviparous seeds, examining two of the mangrove species from tropical Queensland. Lilian Fraser has two papers upon the sooty moulds of New South Walesthose curious fungi that are found superficial upon branches and leaves, living upon the honey-dew secreted by scale insects and aphides; she also describes some of the Mycetozoa of the same State. I. V. Newman, in continuation of earlier studies of the Australian acacias, has two papers dealing with the floral organs and their development, fertilisation and embryology in Acacia Baileyana, whilst Joyce W. Vickery deals with the vegetative reproduction by underground tubers of two species of Drosera common as winter herbs in the Sydney district. The Botanical Department thus bears witness to its active interest in the flora of the Australian dominion.

\section{Hydrogen Ion Determination}

WE have received a copy of the fourth revised and enlarged edition of the booklet " $p \mathrm{H}$ Values", which may be obtained free on application to British Drug Houses, Ltd., Graham Street, City Road, London, N.1. The booklet gives an elementary account of the subject, with particular reference to indicators. It is based entirely on the idea of a concentration of hydrogen ions, and the question arises whether the time has not come to take account of activities and salt effects more adequately than is the case. Further editions of the booklet should be revised so as to bring it more into line with modern practice.

\section{Popular Reading of Scientific Books}

THE librarian of Middlesbrough Public Libraries has made an interesting experiment in endeavouring to guide his readers towards an intelligent use of works of general science. A pamphlet entitled "How to Understand the Sciences" (pp. 28) offers a very readable commentary upon well-known books dealing with scientific subjects in a popular way, and suggests a graduated course of reading, suitable for the plain man, in physics, chemistry, biology and general science. If Mr. Lillie's comments do not increase the intelligent reading of the scientific works in his libraries by the ordinary citizen, nothing will.

\section{Association of American Geographers}

THE thirty-second annual meeting of the Association of American Geographers was held on December 30-January 1 at Washington University, St. Louis, Missouri. In the three-day session, seventy-two papers were presented, including six in the field of geomorphology, ten in meteorology and climate, twenty-two in regional geography, six in the field of population, and two in cartography. The remainder represented a diversity of subjects. The morning of January 1 was devoted to a symposium of "Land Utilisation". The papers on this subject were presented by Prof. Lester E. Klimm of the University of Pennsylvania, Prof. H. M. Leppord of the University of Chicago, Prof. Loyal Durand, jun. of the University of Wisconsin, Dr. G. Donald Hudson of the Tennessee Valley Authority and Prof. K. C. McMurray of the University of Michigan. On the evening of December 31, the retiring president, Charles C. Colby of the University of Chicago, addressed the Associa. tion and guests on the subject of "Changing Currents of Geographical Thought in America". The following officers were elected for 1936 : President, Prof. W. H. Hobbs, University of Michigan ; Vice-President, Dr. John K. Wright, librarian of the American Geo. graphical Society; Secretary, Prof. P. E. James, University of Michigan; Treasurer, Prof. John E. Orchard, Columbia University ; Members of Council, Col. Claude E. Birdseye, U.S. Geological Survey (one year), and Prof. R. J. Russell, Louisiana State University (three years).

\section{British Medical Association}

The one hundred and fourth annual meeting of the British Medical Association will be held in Oxford on July 17-24. The president-elect is Sir E. Farquhar Buzzard, regius professor of medicine in the University of Oxford. The meeting will be divided into the following sections with the presidents indicated: Medicine (Dr. A. G. Gibson); Surgery (Prof. G. E. Gask); Obstetrics and Gynæcology (Prof. H. B. Whitehouse); Pathology and Bacteriology (Dr. E. W. A. Walker) ; Diseases of Children (Dr. R. C. Jewesbury); Neurology and Psychological Medicine (T. S. Good); Ophthalmology (Dr. P. E. H. Adams); Orthopædics (G. R. Girdlestone); Oto. Rhino-Laryngology (L. Golledge); Pharmacology and Therapeutics with Anæsthetics (Prof. J. A. Gunn); Physical Medicine (Dr. W. J. Turrell); Physiology and Biochemistry (Prof. R. A. Peters); Radiology (R. H. Sankey); Anatomy (Prof. W. E. Le Gros Clark); Dermatology (Dr. S. E. Dore); History of Medicine (Dr. A. Chaplin); Medical Sociology (Sir George Newman); Nutrition (Dr. A. F. Hurst); Public Medicine (Dr. W. M. Willoughby); Tuberculosis (Dr. W. Stobie). Further information can be obtained from the Secretary, B.M.A. Office, The Cottage, Keble Road, Oxford.

\section{Second International Congress for Microbiology}

The second International Congress for Microbiology will be held in London on July 25-August 1 under the presidency of Prof. J. C. G. Ledingham. The head. quarters of the Congress will be at University College, Gower Street, W.C.I, but additional accommodation, if required, will be available in the adjacent buildings of the London School of Hygiene and Tropical Medicine and the Wellcome Research Institution. During the Congress week, official receptions will be given by His Majesty's Government, by the Royal Society and other official bodies. Excursions have been arranged by the Ladies' Committee for the ladies and any members of Congress desiring to take part in them. Also the Sectional Committees are arranging visits to laboratories and institutes concerned with the scientific business of the sections. Extended excursions are being arranged for the 